\title{
Sea-Salt Particles in the Middle Troposphere over the Tropical Pacific Ocean
}

\author{
by \\ Miwako Ikegami, Kikuo Okada and Yuji Zaizen \\ Meteorological Research Institute, Tsukuba, Ibaraki, 305 Japan \\ (Received August 1,1990 ; Revised January 9,1991)
}

\begin{abstract}
During the INSTAC- I flight campaign, aerosol number-size distribution was measured in the middle troposphere at $4-5 \mathrm{~km}$ altitude from $0^{\circ} \mathrm{N}$ to $34^{\circ} \mathrm{N}$ by using an optical counter. Aerosol particles were also collected for electron microscopic examinations. Two features of spatial distribution of aerosols were observed over the tropical areas. Sulfuric acid was detected in the particles with a wide size range where the concentrations showed uniform spatial distribution with low values. On the other hand, high aerosol concentrations in which sea-salt particles were dominant instead of sulfuric acid were observed intermittently with space and found to be associated with the existence of convective clouds. The upward transport of sea-salt particles through convective clouds is considered to be responsible for high particle concentrations in the middle tropical troposphere. This suggests that the vertical transport of sea-salt particles would influence the microphysical properties of clouds in the middle and upper troposphere.
\end{abstract}

\section{Introduction}

Atmospheric aerosol particles play an important role in atmospheric radiation and cloud physical processes. Increasing attention has been devoted to the global changes in the concentration of aerosol particles and their chemical composition. Although measurements on number-size distribution of aerosols have been made in the lower troposphere by many investigators, little is known about the size and spatial distribution of aerosols in the middle troposphere (e.g., Blifford and Ringer, 1969 ; Gillette and Blifford, 1971 ; Patterson et al., 1980 ;

(C)1991 by the Meteorological Research Institute
Lechner et al., 1989). Sulfuric acid particles are usually found to be present in the middle troposphere (Bigg, 1977 ; Ono, 1978 ; Ikegami et al., 1980 ; Yamato and Ono, 1989). However, information on the chemic al composition of middle tropospheric particles is also meager at present. Since the height of convective clouds often goes beyond the top of the boundary layer, more detailed observation on the behavior and features of aerosol particles in the middle troposphere should be carried out in association with the presence of clouds.

During the INSTAC- I (International Strato/Tropospheric Air Chemistry / 7-10 March in 1989) flight, measurements on the number-size distribution of aerosol parti- 
cles in the middle troposphere from $0^{\circ} \mathrm{N}$ to $34^{\circ} \mathrm{N}$ were carried out, concurrently with the collection of aerosol particles. The aim of this paper is to show and discuss the spatial distribution of aerosol particles over the tropical Pacific Ocean where convective cloud formation is active and to discuss this in relation to the chemical composition of aerosol particles.

\section{Methods}

Aircraft (Marlin- V ) observation was carried out on board at an altitude of $4-5$ $\mathrm{km}$ from $0^{\circ} \mathrm{N}$ to $34^{\circ} \mathrm{N}$ during the INSTAC- I campaign (Fig. 1). The present paper used the data gathered over the tropical Pacific Ocean $\left(0^{\circ} \mathrm{N}-23^{\circ} \mathrm{N}\right)$. The numbersize distribution of aerosol particles of

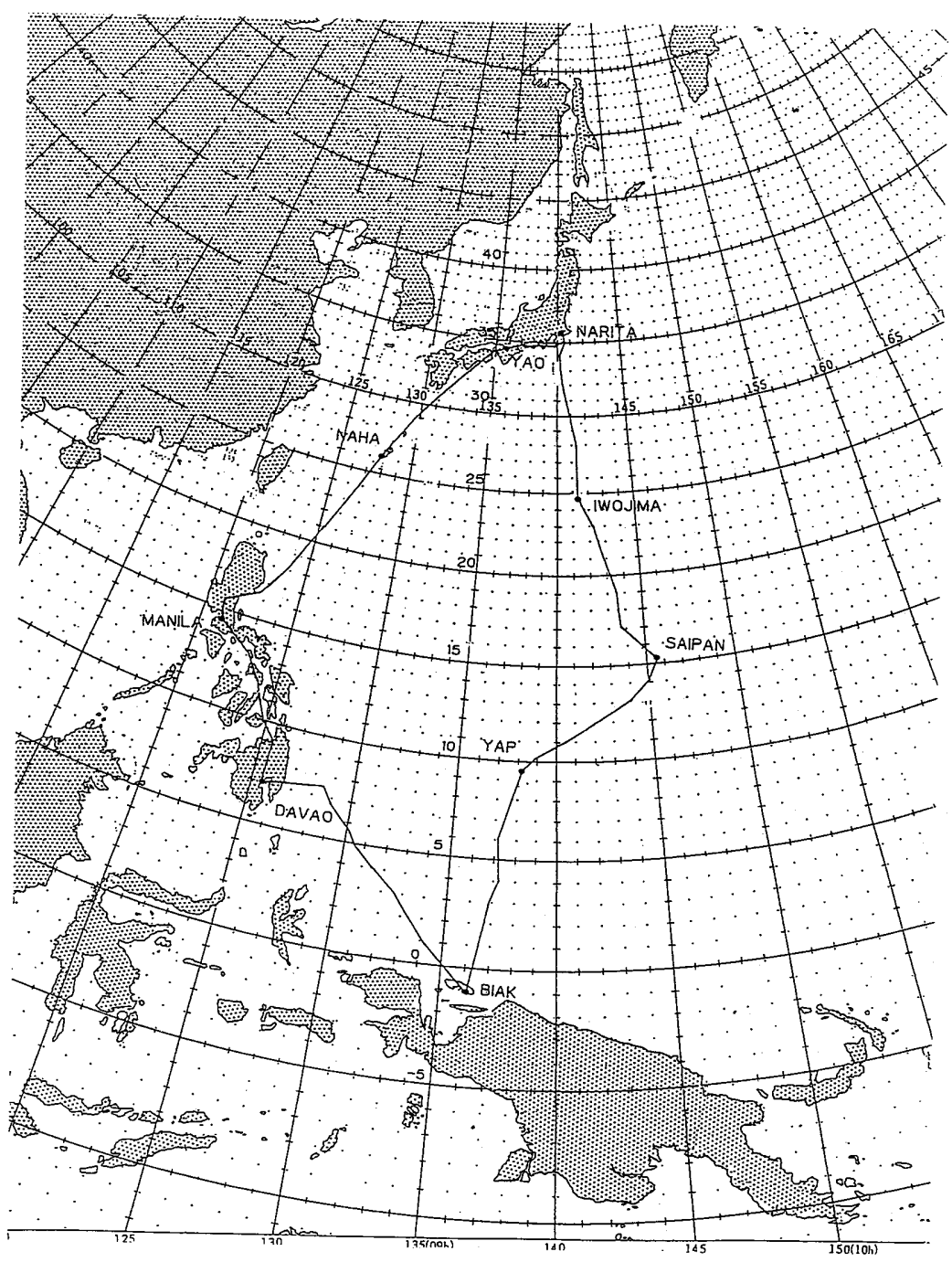

Fig. 1 Courses of the INSTAC- I flight. Southbound flight: NaritaSaipan ( 7 March) and Saipan-Biak ( 8 March). Northbound flight : Biak-Manila ( 9 March) and Manila-Yao (10 March). Measurements were carried out at an altitude of $4-5 \mathrm{~km}$. 
Table 1. Impactors used in the INSTAC- I observation. The observation was carried out at an altitude of $4.5 \mathrm{~km}$ (atmospheric pressure $=600 \mathrm{mb}$ ).

\begin{tabular}{lccccc}
\hline & $\begin{array}{c}\text { Particle radius } \\
(\mu \mathrm{m})\end{array}$ & $\begin{array}{c}\text { Jet diameter } \\
(\mathrm{mm})\end{array}$ & $\begin{array}{c}\text { Flow rate } \\
(\ell / \mathrm{min})\end{array}$ & $\begin{array}{c}\text { Pressure drop } \\
(\mathrm{mmHg})\end{array}$ & $\begin{array}{c}\text { Sampling Period } \\
(\mathrm{min})\end{array}$ \\
Impactor & $>0.3$ & 1.0 & 6.3 & not measured & 8 \\
$\begin{array}{l}\text { Low-pressure } \\
\text { Impactor }\end{array}$ & $0.03-0.35$ & 0.5 & 1.3 & $-380^{*}$ & 60 \\
\hline
\end{tabular}

* : Air pressure below the jet was evaluated to be $70 \mathrm{mmHg}$.

$0.15-5 \mu \mathrm{m}$ radius was measured with an optical particle counter (Dansangyo Co. Ltd., Model PM-730) which has a 15-channel discriminator. The detection limit of particles of $>1 \mu \mathrm{m}$ radius is estimated to be $10^{-3}$ (particles $\mathrm{cm}^{-3}$ ) for the measuring time of $3 \mathrm{~min}$. $\left(900 \mathrm{~cm}^{3}\right)$ used in this observation. The counter was calibrated by using latex particles before the observation. Individual aerosol particles of $>0.3$ $\mu \mathrm{m}$ radius were collected on carbon-covered nitrocellulose (collodion) films with an impactor of $1-\mathrm{mm}$ diameter jet. In order to collect small particles of $0.03-0.35 \mu \mathrm{m}$, a low-pressure impactor (Okada, 1983) was also used. The sampling situation is summarized in Table 1.

The particles collected were examined with an electron microscope (Hitachi, $\mathrm{H}-600)$ in order to obtain the size and morphology. An X-ray spectrum was also obtained from the center of individual particle by using an energy-dispersive $\mathrm{X}$-ray analyzer (Kevex, delta V) through a Kevex. UTW detector. Since the collecting surface used in the present study is the thin film mentioned above, $\mathrm{C}, \mathrm{N}$ and $\mathrm{O}$ elements are detected from the film alone.

\section{Results}

Two characteristic features of spatial change in aerosol number concentration were observed in the tropical middle troposphere as shown below.

\section{a) Small spatial change in aerosol concentra- tion}

Fig. 2 shows the spatial distributions of aerosol number concentrations along the southbound flight from $14^{\circ} \mathrm{N}$ to $10^{\circ} \mathrm{N}$ at an altitude of approximately $4.3 \mathrm{~km}$. Aerosol radius range was classified into 4 classes: $0.15 \leqq r<0.25 \mu \mathrm{m}, 0.25 \leqq r<0.5 \mu \mathrm{m}, 0.5$ $\leqq r<1 \mu \mathrm{m}$ and $1 \mu \mathrm{m} \leqq r$, where $r$ is particle radius. Submicron aerosols $(<1 \mu \mathrm{m}$ radius) show small changes in number concentrations, within a factor of 3 . Number concentrations of particles of $0.15-1 \mu \mathrm{m}$ radius are low values ranging from 0.2 to $0.3 \mathrm{~cm}^{-3}$. Particles of $\geqq 1 \mu \mathrm{m}$ radius show large spatial variability of concentration in this region due to the counting error in the situation of the low particle concentration. The averaged number-size distribution of aerosols in this region. (Fig. 3) shows that the concentrations of particles with radii greater than $0.15 \mu \mathrm{m}$ are less than $1 \mathrm{~cm}^{-3}$ as expressed in $\mathrm{d} N / \mathrm{d} \log r$. Fig. 4 shows electron micrograph of particles collected in this region. Most of the small particles (Fig. 4a) collected with a low-pressure impactor consist of a central particle surrounded by satellite droplet rings on the collecting surface, which is the characteristic morphology of sulfuric-acid containing particles (e.g., Frank and Lodge, 1967). Though not shown here, the X-ray spectra of central particles with satellite droplet rings in Fig. $4 \mathrm{a}$ indicated the presence of element S. Whereas particles (Fig. 4b) 


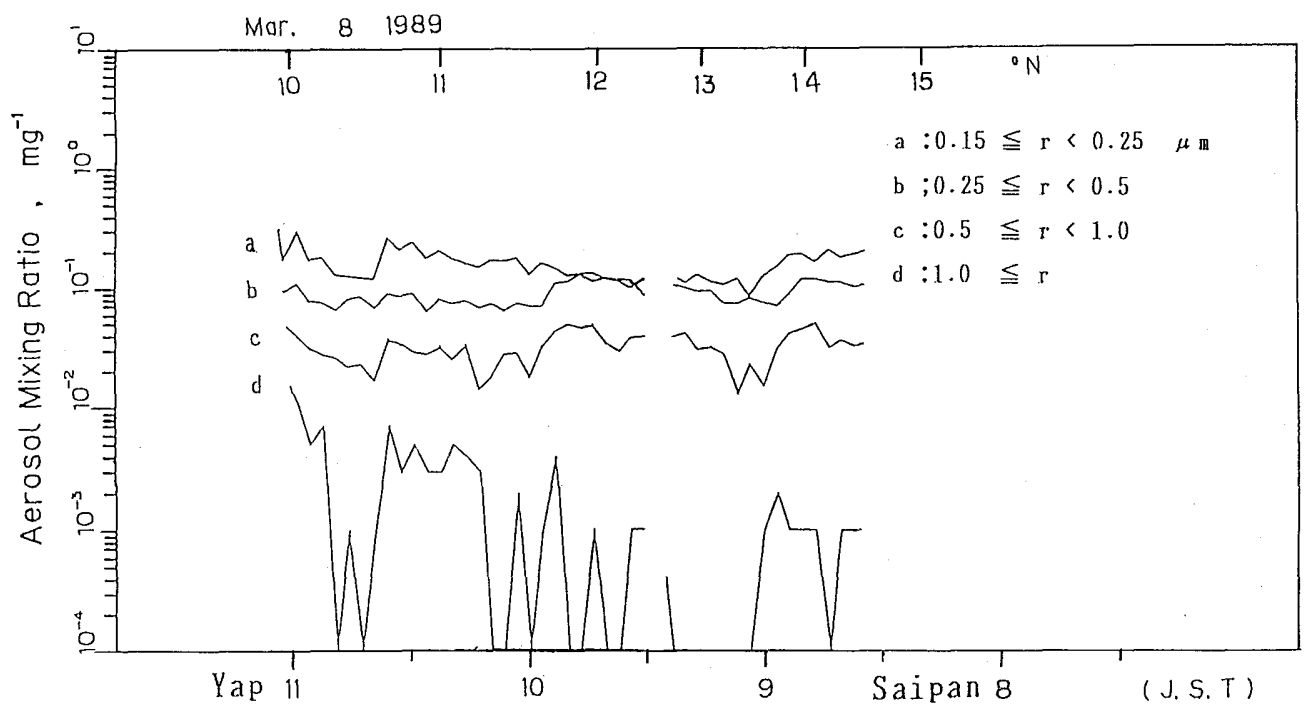

Fig. 2 Spatial change in number concentrations of aerosols from $10^{\circ} \mathrm{N}$ to $15^{\circ} \mathrm{N}$ measured on the morning of 8 March 1989. Aerosol radius range was classified into 4 classes : $0.15 \leqq r<0.25 \mu \mathrm{m}, 0.25 \leqq r<0.5 \mu \mathrm{m}, 0.5 \leqq r<1 \mu \mathrm{m}$ and $1 \mu \mathrm{m} \leqq r$, where $r$ is particle radius. Detection limit of particles of $\geqq 1 \mu \mathrm{m}$ radius is estimated to be $10^{-3} \mathrm{~cm}^{-3}$.

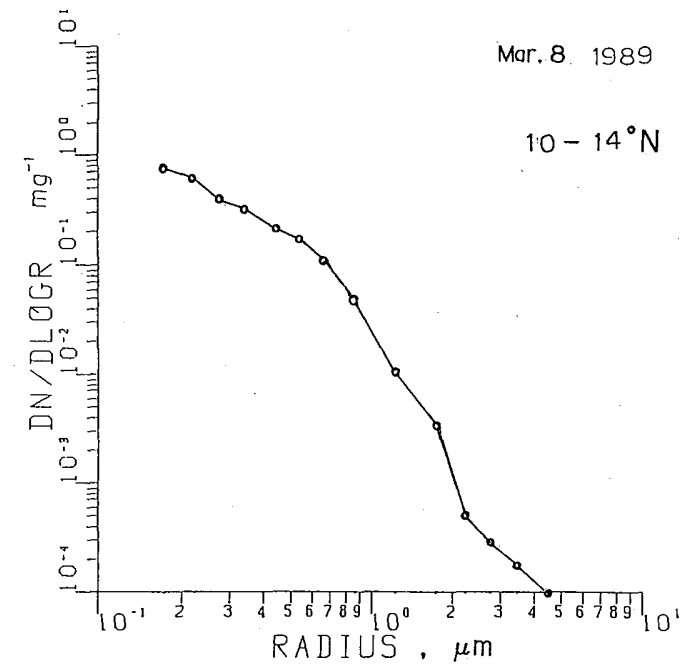

Fig. 3 Averaged number-size distribution of aerosols from $10^{\circ} \mathrm{N}$ to $14^{\circ} \mathrm{N}$. evaluated to be $>1 \mu \mathrm{m}$ radius also exhibit similarity to those in Fig. $4 \mathrm{a}$ in morphological features. The above results indicate that the dominant particles in the middle troposphere from $10^{\circ} \mathrm{N}$ to $14^{\circ} \mathrm{N}$ were sulfuric acid.

The spatial distribution of aerosol number concentrations from $0^{\circ} \mathrm{N}$ to $23^{\circ} \mathrm{N}$ along the northbound flight is illustrated in Fig. 5. Relatively uniform spatial-distribution with low number concentrations of aerosols was observed at $<1^{\circ} \mathrm{N}, 9^{\circ} \mathrm{N}-12^{\circ} \mathrm{N}$ and $12^{\circ} \mathrm{N}-23^{\circ} \mathrm{N}$. Averaged number-size distributions of aerosols at $<1^{\circ} \mathrm{N}, 9^{\circ} \mathrm{N}-12^{\circ} \mathrm{N}$ and $12^{\circ} \mathrm{N}-23^{\circ} \mathrm{N}$ are given in Fig. 6 . In the submicron size range, a difference in the concentration is found within a factor of 5 . The number-size distribution of aerosols can be expressed by the following equation : $\mathrm{d} N / \mathrm{d} \log r=C r^{-\beta}$ (Junge, 1963), where $N$ is the number concentration of particles per unit air mass $\left(\mathrm{cm}^{-3}\right)$ per unit $\log$ size interval, $C$ is a constant and $-\beta$ is the 


\section{$4 a$}

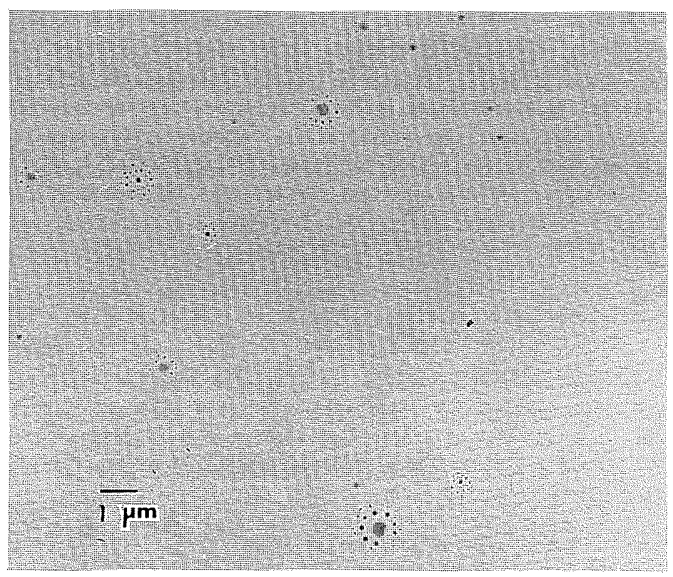

$4 \mathrm{~b}$

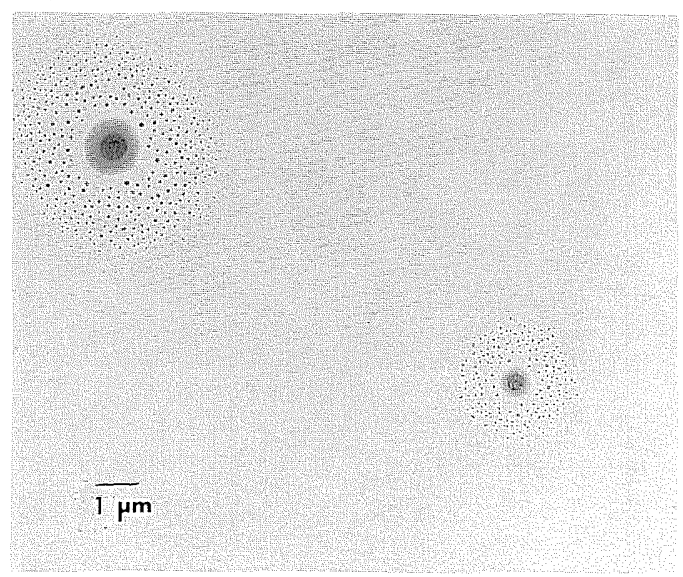

Fig. 4 Electron micrograph of small particles collected with the low-pressure impactor during the period from 08: 20 to 09:20 JST on 8 March $1989\left(15^{\circ} \mathrm{N}-13^{\circ} \mathrm{N}\right)$ (a). Electron micrograph of large particles collected during the period from $08: 23$ to $08: 30$ JST on 8 March $\left(15^{\circ} \mathrm{N}\right)$ (b).

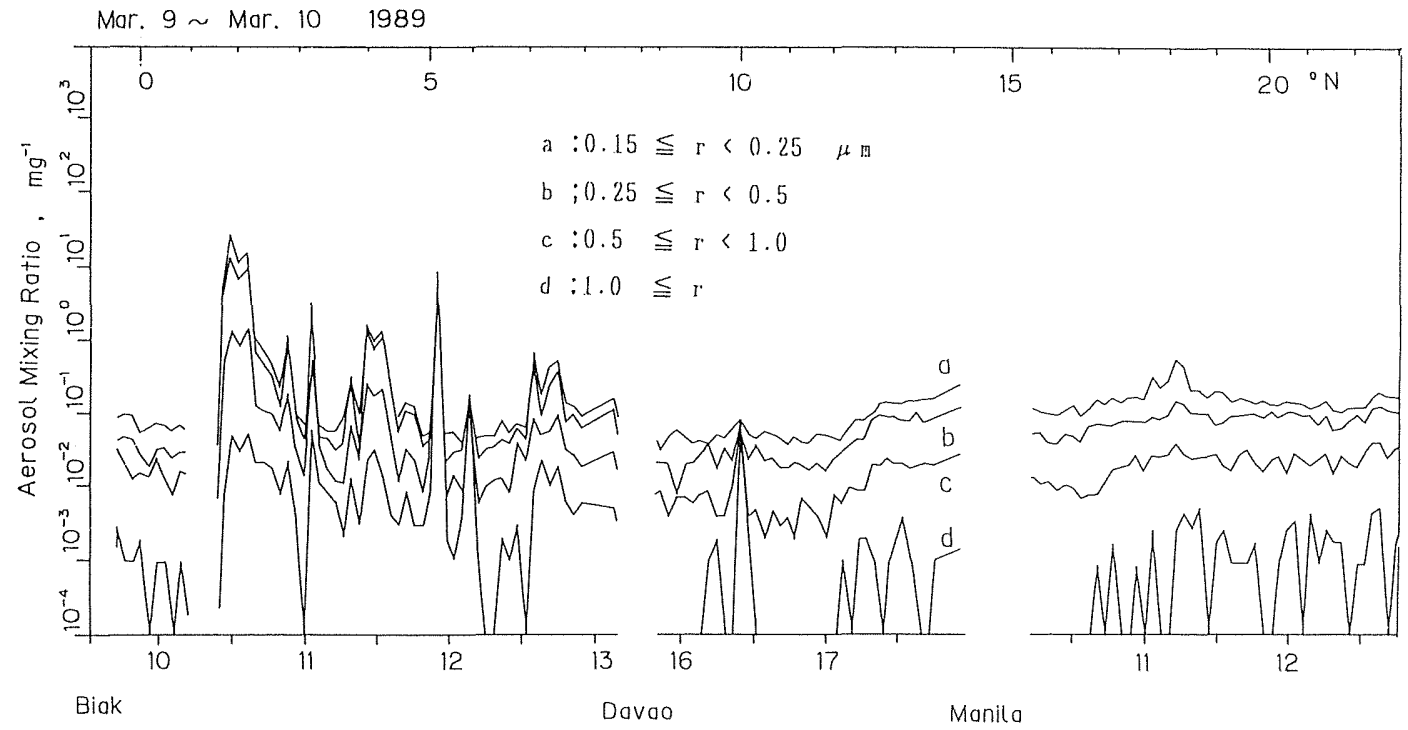

Fig. 5 Spatial change in number concentrations of aerosols from $0{ }^{\circ} \mathrm{N}$ to $23^{\circ} \mathrm{N}$ measured during the northbound flight ( 9 to 10 March 1989). 


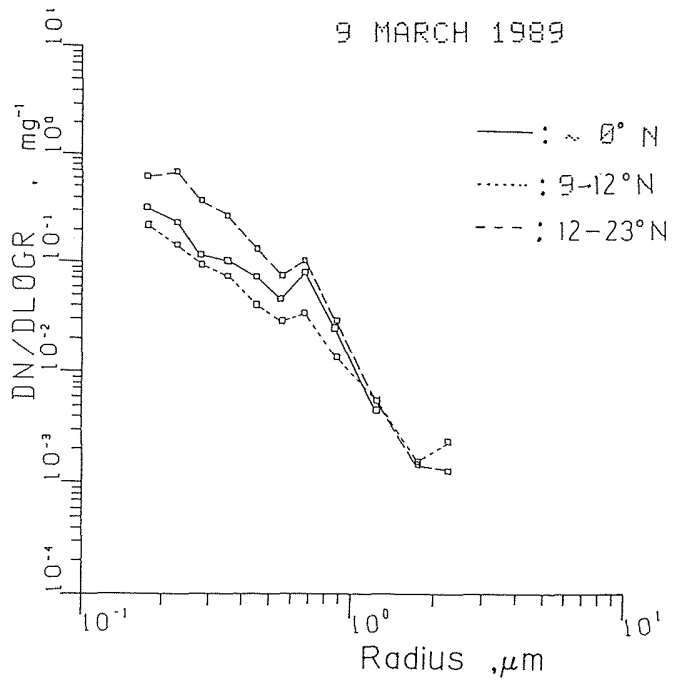

Fig. 6 Averaged number-size distributions of aerosols measured at $0^{\circ} \mathrm{N}, 9^{\circ} \mathrm{N}$ $12^{\circ} \mathrm{N}$ and $12^{\circ} \mathrm{N}-23^{\circ} \mathrm{N}$ where the concentrations were relatively uniform spatially.

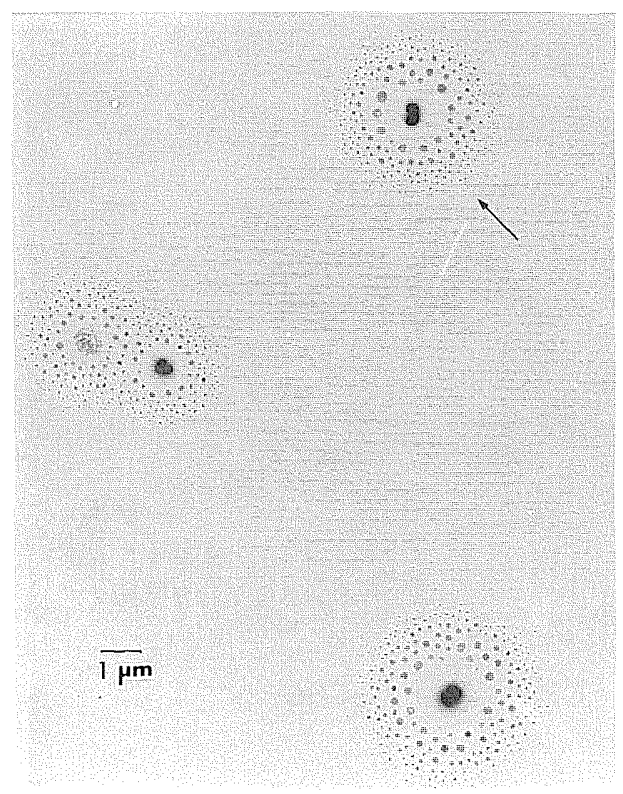

"Junge" slope. It is found from Figs. 3 and 6 that the values of $-\beta$ were 1.5 in the radius range between 0.1 and $1 \mu \mathrm{m}$. These results are due to low concentrations of submicron particles (less than $1 \mathrm{~cm}^{-3}$ as expressed in $d N / d \log r$ ). Fig. 7 shows an electron micrograph of aerosol particles collected at $0^{\circ} \mathrm{N}$. Particles on the collecting surface show the morphological features identical to those in Fig. 4. The X-ray spectrum from the particle marked by an arrow in Fig. 7 shows the presence of S, indicating that sulfuric acid dominates the particles. Though not shown here, particles collected at $15^{\circ} \mathrm{N}-17^{\circ} \mathrm{N}$ in the north bound flight contained sulfuric acid. It is clear that sulfuric acid particles were dominant in a wide size range in the situation of relatively uniform spatial distribution with low particle concentrations.
b ) Large variability of number concentration with space

As seen in Fig. 5, aerosol concentra-

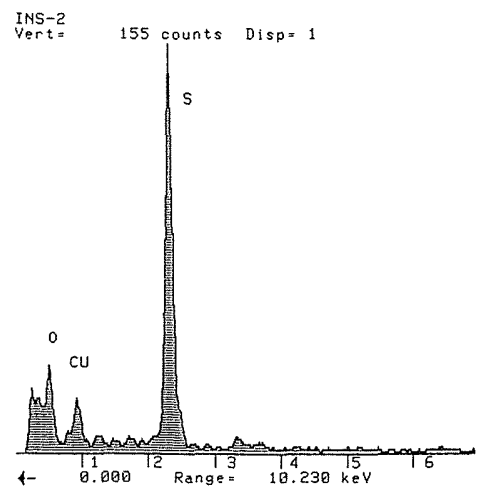

Fig. 7 Electron micrograph of large particles collected during the period from 10 11 to $11: 18$ JST on 9 March $\left(0^{\circ} \mathrm{N}\right)$ and X-ray spectrum of particles shown by an arrow. 
tions were intermittently high over the $2^{\circ} \mathrm{N}-8^{\circ} \mathrm{N}$ region. A view from the aircraft taken at 11:59 JST on 9 March $\left(5^{\circ} \mathrm{N}\right.$, Fig. 8) indicates the presence of many convective clouds. The concentrations varied on the order of 2 . In this region, aerosol concentrations became maximum during the incloud flight. Although the relative humidity in the entire regions was close to $100 \%$, low concentrations were observed in the cloud-free atmosphere. Fig. 9 shows

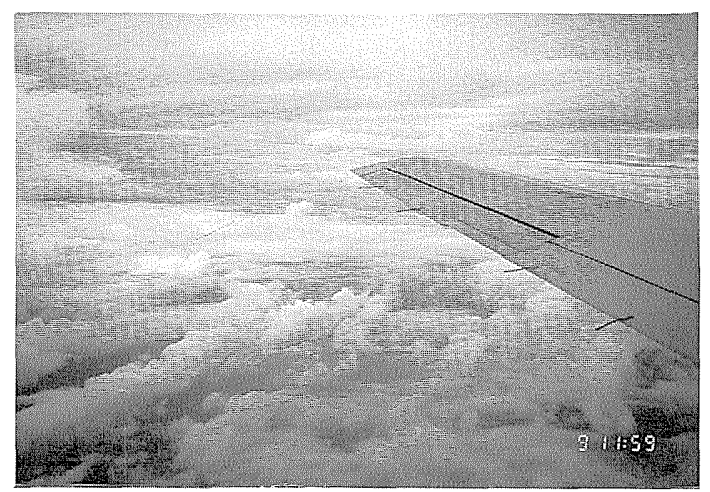

Fig. 8 View from the aircraft at $11: 59$ JST on 9 March $1989\left(5^{\circ} \mathrm{N}\right)$. the averaged number-size distributions in the cloudy and cloud-free atmospheres. The distribution pattern in the cloud-free atmosphere is similar to that observed in

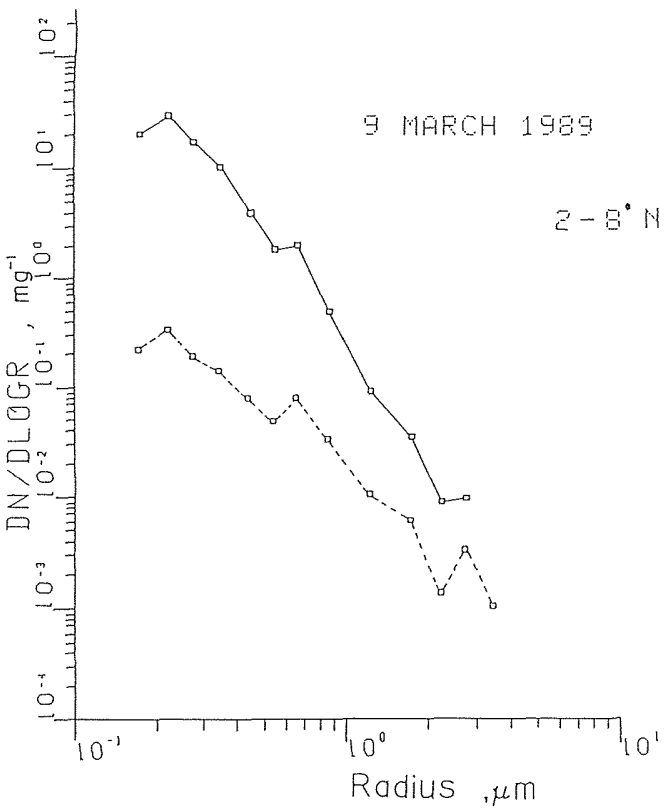

Fig. 9 Averaged number-size distributions of aerosols in the cloudy and cloudfree atmosphere.
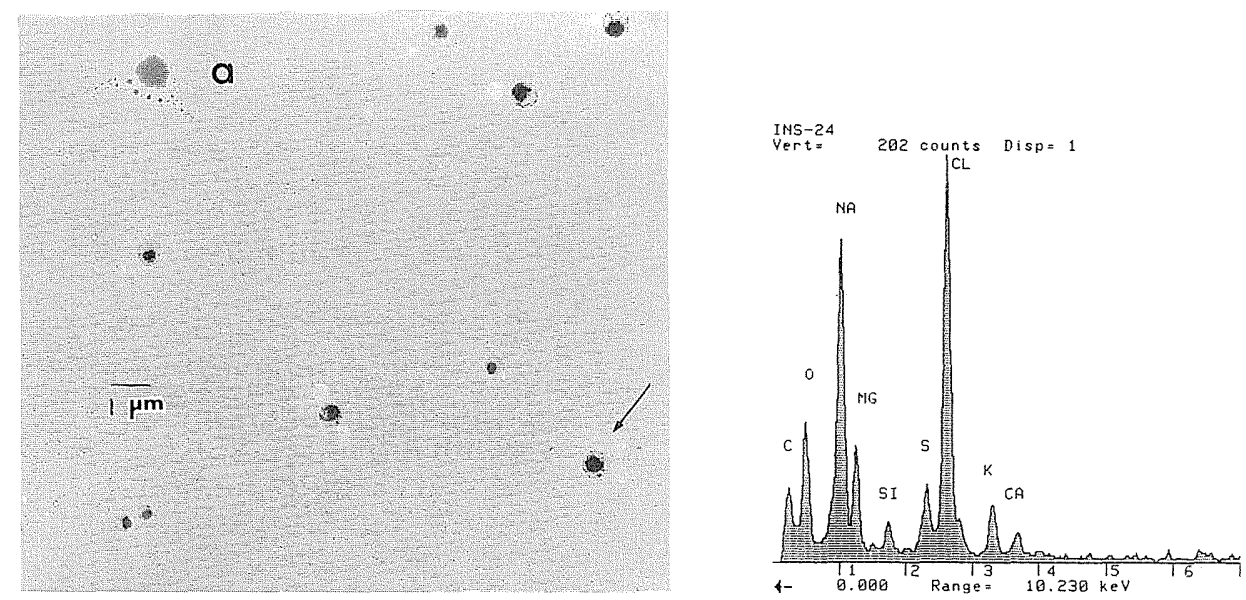

Fig. 10 Electron micrograph of particles collected with the low-pressure impactor during the period of $11: 15-12: 15$ JST on $9 \operatorname{March}\left(3.5^{\circ} \mathrm{N}-6^{\circ} \mathrm{N}\right)$ and X-ray spectrum of particle indicated by an arrow. Particle by a is sulfuric-acid containing particle. 
the regions (Fig. 6) in which the uniform spatial distributions were present. The aerosol concentrations in clouds are 1-2 orders of magnitude greater than those in the cloud-free atmosphere. Fig. 9 also shows that the concentration increased strongly with decreasing radius as compared to that in the cloud-free atmosphere. These results suggest that the increased aerosol concentrations in the middle troposphere is caused by the presence of clouds. Fig. 10 shows an electron micrograph of small particles collected at $4^{\circ} \mathrm{N}-6^{\circ} \mathrm{N}$. Most of the particles have morphological features similar to sea-salt, not to sulfuric acid and sulfate. The $\mathrm{X}$-ray spectrum of the particle shown by an arrow in Fig. 10 shows the dominant presence of $\mathrm{Na}$ and $\mathrm{Cl}$, along with the relatively small content of $\mathrm{Mg}, \mathrm{S}, \mathrm{K}$ and Ca. Note that the sulfuric-acid containing particle marked by a in the figure is also collected. X-ray analysis and morphological examination showed that sea-salt particles comprised $67 \%$ of the total number of particles in the radius range of $0.08-0.3$ $\mu \mathrm{m}$. While sulfate particles including sulfuric acid constituted $27 \%$.

Sea-salt particles were also collected abundantly over the tropical Pacific Ocean during the southbound flight (between Yap and Biak). Fig. 11 shows an electron micrograph of small particles collected at $3^{\circ} \mathrm{N}-6^{\circ} \mathrm{N}$ where convective clouds were being formed actively. Particles with

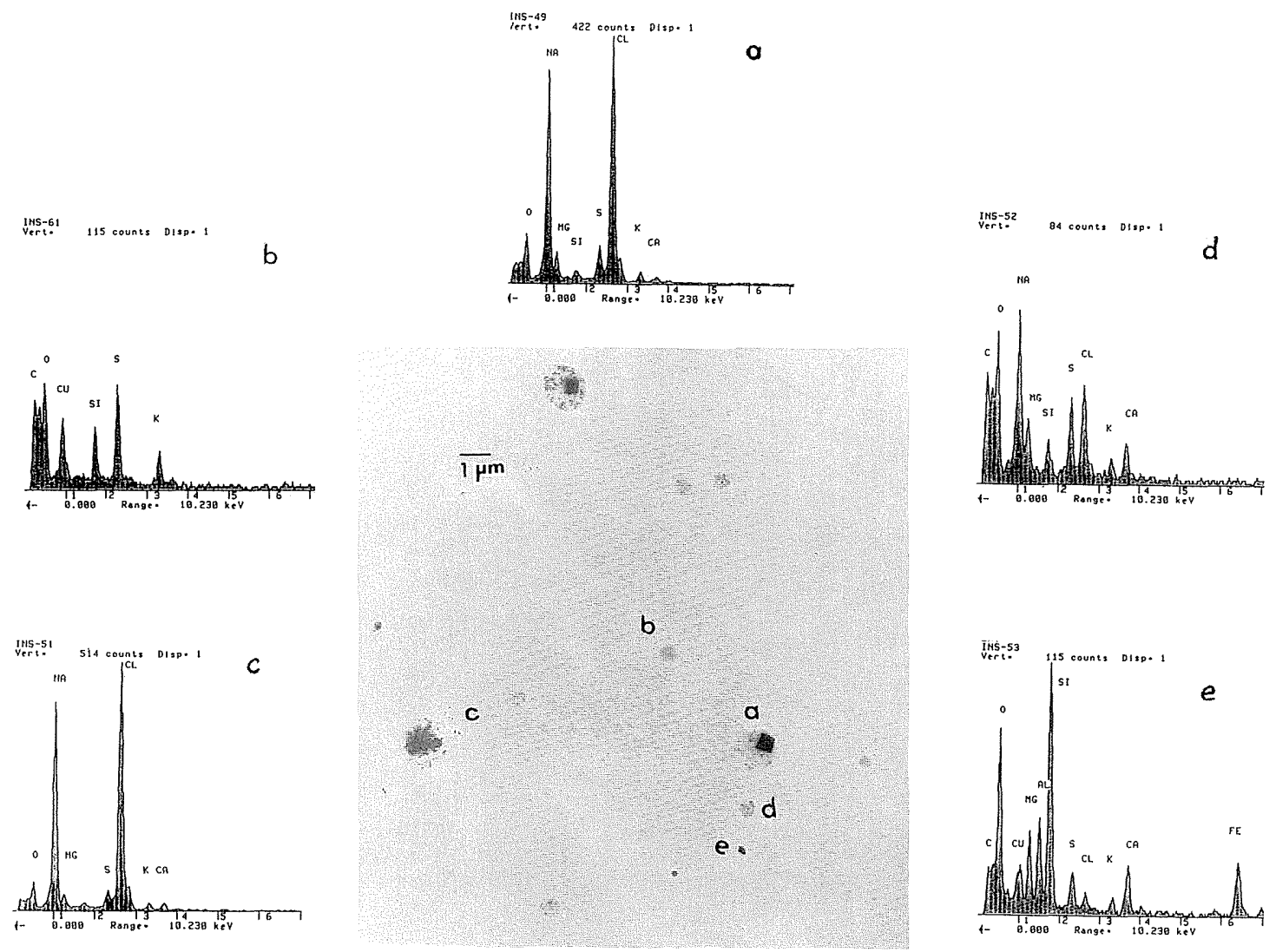

Fig. 11 Electron micrograph of particles collected with the low-pressure impactor during the period of 13: 51-14:51 JST on $8 \operatorname{March}\left(3^{\circ} \mathrm{N}-6^{\circ} \mathrm{N}\right)$ and X-ray spectra of particles a, b, c, d and e. 
square-shaped material are found mainly in the figure. The $\mathrm{X}$-ray spectrum from the central part of the particle indicated by a shows strong peaks for $\mathrm{Na}$ and $\mathrm{Cl}$ together with $\mathrm{Mg}, \mathrm{S}, \mathrm{K}$ and $\mathrm{Ca}$, indicating sea-salt. Although particle $\mathrm{c}$ shows dendritic morphology, the X-ray spectrum of the particle exhibits elemental composition similar to particle a. At present, we can not explain the formation of different morphologies in spite of similar elemental composition. Particle $d$ is considered to be made up of transparent crystalline material on the collecting surface. Particles showing these features are also found in this figure. The $\mathrm{X}$-ray spectrum from particle $\mathrm{d}$ clearly shows the presence of $\mathrm{Na}$ and $\mathrm{Cl}$, along with $\mathrm{S}$. The $\mathrm{Cl}$ peak is lower than that of $\mathrm{Na}$, suggesting the occurrence of $\mathrm{Cl}$ deficiency in sea-salt particles. As seen in Fig. 11, sea-salt particles are dominant $(65 \%)$ in the total number of particles of $0.08-0.3 \mu \mathrm{m}$ radius. Mineral particles (for example, particle e) are also detected in the sample. Sulfuric-acid containing particles (for example, particle b) comprised $9 \%$ of the total number of the particles. The results on the concentration and composition of aerosol particles in the entire region from $0^{\circ} \mathrm{N}-34^{\circ} \mathrm{N}$ are given in another paper (Ikegami et al., 1990).

\section{Discussion}

Sulfuric acid particles were dominant in a wide size range in the situation of a low concentration of particles in the tropical middle troposphere. As reported by Bigg (1977), Ono (1978), Ikegami et al. (1980), Yamato and Ono (1989), sulfuric acid particles are usually present in the middle troposphere instead of sulfate (neutralized) particles. In the present study, the number-size distributions of aerosols in which sulfuric acid particles were dominant exhibited relatively small values of the "Junge" slope (1.5) in the cloud-free troposphere. Small values of the slope $(\sim 2)$ were also observed in the free troposphere of the Northern Hemisphere by Blifford and Ringer (1969). They suggested that size distribution with a small slope would be formed through the aging process. Patterson et al. (1980) showed, on the basis of the measurements in the marine free troposphere, that the aerosol mass concentration in the Southern Hemisphere was dominated by particles of $<0.5 \mu \mathrm{m}$ radius, while 1 arger particles were more important in the Northern Hemisphere. In the present study, sulfuric acid particles with radii greater than $1 \mu \mathrm{m}$ were collected in the middle troposphere. It is suggested that growth (aging) of sulfuric acid particles should occur in the ammonia-minor atmosphere for a long time. The growth would make a size distribution with a low value of the slope.

The present study indicates that the predominance of sea-salt particles in the tropical middle troposphere is closely associated with the presence of convective clouds. As suggested by Patterson et al. (1980), the high aerosol concentrations should be due to the vertical transport of particles by cloud pumping. Because seasalt particles can act as cloud condensation nuclei ( $\mathrm{CCN})$, the high concentrations should be due to the supply of residues of cloud droplets which contained sea-salt. Sulfuric acid particles are basically impor tant as background aerosols. In the remote oceanic atmosphere, non sea-salt sulfate particles are usually dominant in the radius range of $<0.1 \mu \mathrm{m}$ (e.g., Mészáros and Vissy, 1974 ; Okada et al., 1985). However, the results of the present research show that sea-salt particles were dominant in particles of $0.08-0.3 \mu \mathrm{m}$ radius in the cloudy atmosphere. Mészáros and Vissy (1974) found that the number concentration of sea-salt particles in the radius range of $0.1-1 \mu \mathrm{m}$ tended to increase with wind velocity and were larger than those of ammonium sulfate under wind conditions stronger than $10 \mathrm{~ms}^{-1}$. Wind velocity greater than $10 \mathrm{~ms}^{-1}$ was observed over the ocean when severe convective clouds were present 
(Houze, 1977 ; Ishihara and Yanagisawa, 1982). Consequently, it is considered that more submicron sea-salt particles would be originated from the sea surface and be incorporated into cloud droplets efficiently. Hence, we suggest that the vertical transport through convective clouds would contribute largely to the increase in particle concentration in the free troposphere where the concentration is usually very low. Supply of aerosol particles including seasalt over the tropical regions is important to assess the global particle transport (e.g., Yamazaki et al., 1989). Moreover, supply of sea-salt particles in the free troposphere may be important in changing the cloud microstructure formed in the middle and upper troposphere through nucleation scavenging.

\section{Summary and conclusions}

In the INSTAC- I flight campaign, the number concentration of aerosol particles with radii between 0.15 and $5 \mu \mathrm{m}$ was measured in the middle troposphere of $4-5 \mathrm{~km}$ altitude, together with the collection of aerosol particles. The results of the measurements in the tropical atmosphere are summarized as follows ;

1) Sulfuric acid particles were dominant in a wide size range in the situation of relatively uniform aerosol spatial-distribution with low particle concentrations. Sulfuric acid particles are basically important as background aerosols.

2 ) Spatial distribution of aerosols in the tropical middle troposphere is influenced strongly by the vertical transport of aerosols (mainly sea-salt) through convective clouds. The number concentration of sub. micron particles measured in clouds was 1-2 orders of magnitude greater than outside the clouds. The supply of sea-salt as by convective clouds would contribute to increasing the amount of aerosols in the free troposphere where the concentration is usually very low. Consequently, if the convective cloud formation tends to increase, sea-salt particles which will act as $\mathrm{CCN}$ should influence cloud microphysics in the middle and upper troposphere through nucleation scavenging. Sea-salt particles transported will also play an important role in the formation of background particles.

Acknowledgments : —- The authors are grateful to Dr. Y. Sugimura, leader of the INSTAC, the Meteorological Research Institute (MRI), for giving us the opportunity of aircraft observation and $\mathrm{Mr}$. Y. Makino, the MRI, for his help and discussion throughout this study. They are also grateful to Dr. J. Heintzenberg, Stockholm University, for detailed comments and discussion during his stay in the MRI as a guest scientist of the INSTAC program. They also thank to Mr. K. Mori, the MRI, for providing us with meteorological information on the tropical atmosphere.

\section{References}

Bigg, K., 1977 : Some properties of the aerosol at Mauna Loa Observatory. J. Appl. Meteor., 16, 262-267.

Blifford, I. H., Jr. and L. Ringer, 1969 : The size and number distribution of aerosols in the continental troposphere. J. Atmos. Sci., 26, 716-726.

Frank, E. R. and J. P. Lodge, Jr., 1967 : Morphological identification of airborne particles with the electron microscopy. J. Microscopie, 6, 449-456.

Gillette, D. A. and I. H. Blifford, Jr., 1971 : Composition of tropospheric aerosols as a function of altitude. J. Atmos. Sci., 28, 1199-1210.

Houze, R. A., Jr., 1977 : Structure and dynamics of a tropical squall line system. Mon. Wea. Rev., 105, 1540-1567.

Ikegami, K., K. Higuchi and A. Ono, 1980 : Preliminary report on the vertical distribution of aerosol particles over the Nepal Himalayas. Seppyo, 41 ( Special Issue), 86-89.

Ikegami, M., K. Okada and Y. Zaizen, 1990 : Concentration and composition of aerosol particles in the middle troposphere $\left(0^{\circ} \mathrm{N}-34^{\circ} \mathrm{N}\right)$.

Proc. The 3rd International Aerosol Conference,1058-1061.

Ishihara, M. and Z. Yanagisawa, 1982 : Structure 
of a tropical squall line observed on the western tropical Pacific during MONEX. Pap. Met. Geophys., 33, 117-135.

Junge, C. E., 1963 : Air Chemistry and Radioactivity. Academic Press, New York and London, $1-382$.

Lechner, I. S., G. W. Fisher, H. R. Larsen, M. J. Harvey and R. A. Knobben, 1989 : Aerosol size distributions in the southwest Pacific. J. Geophys. Res., 94, 14893-14903.

Mészáros, A. and K. Vissy, 1974 : Concentrations, size distribution and chemical nature of atmospheric aerosol particles in remote oceanic areas. J. Aerosol Sci., 5, 101-109.

Okada, K., 1983 : Nature of individual hygroscopic particles in the urban atmosphere. $J$. Meteor. Soc. Japan, 61, 727-736.

Okada, K., Y. Iwasaka and A. Ono, 1985 : Features of aerosol particles in the remote oceanic atmosphere. Mem. Natl Inst. Polar
Res., 39 (Special Issue), 30-39.

Ono, A., 1978 : Sulfuric acid particles in subsiding air over Japan. Atmos. Environ., 12, 753-757.

Patterson, E. M., C. S. Kiang, A. C. Delany, A. W. Wartburg, A. C. D. Leslie and B. J. Huebert, 1980: Global measurement of aerosol in remote continental and marine regions : Concentration, size distributions, and optical properties. J. Geophys. Res., 85, 7361-7376.

Yamato, M. and A. Ono, 1989 : Chemical and physical properties of stratospheric aerosol particles in the vicinity of tropopause folding. J. Meteor. Soc. Japan, 67, 147-166.

Yamazaki, K., K. Okada and Y. Iwasaka, 1989: Where do aerosol particles in the Antarctic upper troposphere come from ? - A case study in January 1983. J. Meteor. Soc. Japan, 67, 889-905.

\title{
対流圈中部における海塩粒子の存在について 熱帯太平洋上での観測
}

\author{
池上三和子 · 岡田菊夫 ・ 財前祐二
}

INSTAC- I の航空機観測において，日本から赤道まで（ $0^{\circ} \sim 34^{\circ} \mathrm{N} ）$ の中部対流圈（高度 $4 \sim 5 \mathrm{~km} ）$ のエーロ ゾルの測定を行った。本論文では, 特に熱帯域に注目し, 半径0.15 $5 \mu \mathrm{m}$ の粒子の粒径別個数濃度の緯度変化 と，電子顕微鏡による個々の粒子の形態と元素組成について得られた結果を示す。エーロゾルの空間的な分布に

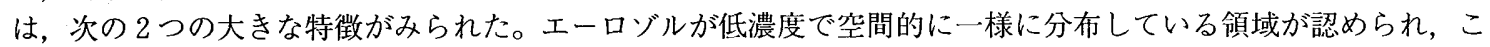
の場合には，広い粒径範囲で硫酸粒子が卓越して存在していることがわかった。一方，粒径によらず濃度が高い 領域が対流雲の存在と対応して存在した。この場合には，硫酸粒子に代わり，海塩粒子が卓越し，高濃度をもた らしていることがわかった。対流雲による海塩粒子の鉛直輸送は，熱帯中部対流圈におけるエーロゾル濃度の増 加に大きな役割を果たし，中部，上部対流圈で形成される雲の微物理特性に影響を与えるものとして重要と考え られる。 